\title{
RETHINKING POE AND WHARTON: FORESHADOWING IN THE STRUCTURE OF GOTHIC STORIES: SIMILARITIES IN EDGAR ALLAN POE'S AND EDITH WHARTON'S SHORT NARRATIVES
}

\author{
Caroline Navarrina de Moura', \\ Lis Yana de Lima Martinez ${ }^{2 i}$ \\ 1UFRGS (Universidade Federal do Rio Grande do Sul), \\ Porto Alegre, Brazil \\ ${ }^{2}$ UFRGS/CNPq (Universidade Federal do Rio Grande do Sul), \\ Porto Alegre, Brazil
}

\begin{abstract}
:
Edgar Alan Poe and Edith Wharton found a way to give their own stories more realistic descriptions and details. The objectives of this research paper are to compare Poe's The Cask of Amontillado (1846) and Wharton's Roman Fever (1934) to know how these tales are structured, to describe how their methods works and how similar they can be. To meet these objectives, both stories were read and analysed so that every foreshadowing clue could be detached from the texts and organized in two tables, Group (1), concerning physical elements, such as titles, names of characters, and objects described, and Group (2), concerning events that took important roles in the stories, such as past events and confessions of the hideous crimes. After gathering all this information together, it was possible to compare those two tables and realise that both authors do have a particular way of thinking about the logic behind the plots by leaving clues throughout the stories that may be only recognized when the reader gets to the end.
\end{abstract}

Keywords: comparative analysis, gothic motifs, Edith Wharton, Edgar Alan Poe

\section{Introduction}

Having faced a rough path during the second half of the eighteenth century by its vulgarity and, consequently, considered inappropriate for the female reader, the Gothic genre emerges with the publication of Horace Walpole's novella The Castle of Otranto in 1764 to appease the public's taste, according to the revolutions that the modern age had been witnessing. By presenting the subheading of 'a gothic story', the exaggerated number of supernatural events, such as helmets and gloves falling from the skies, and other motifs, such as moving paintings, doors, and secret passages, this narrative has been considered the precursor of this new genre, which made it possible for the emergence of its offspring, as the professor and critic Carol Margaret Davison (2009) states it with the publication of Clara Reeve's novel, The Old English Baron (1778), for

i Correspondence: email yana.flafy@gmail.com 
instance, Mathew G. Lewis' The Monk (1794), and Ann Radcliffe's narratives, The Italian (1794) and The Mysteries of Udolpho (1798). Thus, the Gothic genre gained in popularity due to the fact that, even though the last decades of the eighteenth century and the beginning of the nineteenth century hold the events of the French Revolution, and the first and second Industrial Revolutions - which have altered the manner with which the world was socially established, introducing the Age of Reason and the romantic ideas of freedom and equality -, the literary trend seemed to be taking the opposite path and explored deeply the supernatural by exposing the most inner fears and impulses of a whole new world.

Having crossed the seas to the American continent, the Gothic genre found fertile land to grow its roots and to continue to spread the emergence of its offspring since the new-born country, the United States, felt the consequences of the European revolutions, but also experienced important events of their own, such as the Revolutionary War. As a republic, the American country needed to face the new situation it found itself in, a new nation in a new land, directly facing modern and romantic ideas that shaped the world. According to Savoy (2015), Gothic is commonly associated with the dark nightmare that materializes in the basement of the "American dream". The link would even be obligatory since it would be connected to a certain knowledge of the limitations of the American faith in social and material progress. However, Savoy clarifies that the simple association between the convenient figures of the dream and the nightmare is excessively reductive, as these clichés and the impulses of American life they represent are not just in the word layer, but contexts that merge and dialogue with each other. This recognition "will take us far in understanding the odd centrality of Gothic cultural production in the United States, where the past constantly inhabits the present, where progress generates an almost unbearable anxiety about its costs, and where an insatiable appetite for spectacles of grotesque violence is part of the texture of everyday reality". (Savoy, 2015, p. 167)

Thus, the concept of Gothic taken into consideration in this article is the psychoanalytical concept defined by the German professor and psychiatrist Sigmund Freud (1955), who found in its mother tongue the expression Das Unheimlich, which has been translated into English as 'the uncanny', referring to the ambiguous effect an element may have of being familiar and causing awkwardness simultaneously. This notion is expanded by the concept of the American professor and critic Eve Kosofsky Sedgwick (1986) that this effect may be attributed to the relationship among characters and the usage of Gothic motifs to illustrate the unspeakable, enhancing the intensity of suspense in the narratives. Sedgwick (1986) states that the Gothic element should be analysed according to a triad, the structure of the story - whether the narrative follows the pattern of a story within another story, "having to do with the way language treats itself and the relation between signs and meanings" (Sedgwick, 1986) -, the psychoanalytical and the phenomenological aspects of the narrative. The focus of this article lies on the first element of the triad.

In this sense, the Gothic narratives turned into illustrating the inner fears and impulses of a new people, which brings us to the authors related to this article, Edgar Alan Poe and Edith Wharton. Exploring the first-person narrator in order to unravel the deepest layers of the human mind, the former is universally recognized for his great talent in writing short stories and for believing that work of quality should be brief and focus on a specific single effect. To that end, 
he believed that the writer should carefully calculate every sentiment and idea. That is why the way the narratives were structured is so particular:

"Nothing is more clear than that every plot, worth the name, must be elaborated to its dénouement before anything be attempted with the pen. It is only with the dénouement constantly in view that we can give a plot its indispensable air of consequence, or causation, by making the incidents, and especially the tone at all points, tend to the development of the intention." (Poe, 1846, p. 1)

By leaving clues throughout the stories, such as names of characters, places, clothing, and psychological statements, Poe was able to grab every reader's attention to link everything to the endings, creating a greater impact on the public. And that is exactly what we find in Edith Wharton's story: neither the title, nor the dialogues, nor the place in which the narrative is located must be taken for granted. They both articulated what Max Bense (2009) understood as a mathematical description of the world, which builds up the anticipation of a future planned by susceptive reality to varying degrees of restoration.

While the latter, having access to the domestic lives of America's higher classes, Wharton made it possible to explore social and psychological insights since, having experienced herself the misfortunes of a complicated marriage, she managed to give to her own stories more realistic descriptions and details. It is what happens to Wharton's Roman Fever (1934), especially due to the reader's empathy with the characters feelings, and the logical, well-structured flow of the narrative, being possible to compare this particular short story to Edgar Allan Poe's way of constructing his own horror stories, such as The Cask of Amontillado (1846). Even from a primary and uncompromising reading, it could be concluded the evident flirt Poe and Wharton have with the process of "defamiliarization" (Shklovsky, 2015) manifested by their characters' actions as they displace from the everyday common attitudes. This displacement fascinates the reader.

Literary texts share subsidies in a creative, collective and continuous articulation. This notion refers to the understanding of the existence of a common research source, open and available to all writers, which is consulted, not always consciously, during the literary creation process. This font is not just textual, but also social and historical. In this article, we adopt a comparative stance, a practice that allows intertexts to be read in a text and that seeks to decipher how the literary universe is composed and behaves. Therefore, we understand the literary text as a mosaic of multiple other texts written before it and of multiple contexts of creation. Literary studies allow, then, to seek to establish the connections between these texts to make the work collective and highlight the creative character of the textual production process.

Therefore, this article intends to compare both short stories The Cask of Amontillado (1846) and Roman Fever (1934) to analyse how they are structured and to see how similar this structure and the usage of Gothic motifs are, according to Sedgwick's triad. This process is called foreshadowing, which relates to clues the authors choose to leave throughout their works to make a connection to the ending of those stories. Only will the reader realise the elements are hints when they reach the end for the process to be accomplished.

The methodology used to reach the aim of the article is a close reading of the two short stories so that every foreshadowing Gothic motif could be detached from the texts, making a 
separate list of elements. Next, all of these potential clues were grouped in terms of: (1) what kind of clues there are: the title, a name, an object; (2) what part of the story it warns us about: an event and/or a psychological state. For example, in The Cask of Amontillado, the narrator tells us that the event which is about to happen occurs during carnival season in Italy, suggesting some kind of inversion, in this case, from friendship to murder. In Roman Fever, the title suggests at first that what we are about to read is to deal with a common disease at that time in Rome, however, when we get closer to the end, we are able to figure out that the word 'fever' stands for a romantic excitement from the teenagers involved in the story.

In order to properly complete and fulfil the analysis, the contextualisation of Gothic literature both in the United Kingdom and in the United States follows the theories and criticisms of the professors Carol Margaret Davison's History of the Gothic Literature 1764 - 1824 (2009), Charles L. Crow's A Companion to American Gothic (2014), and Eric Savoy's “The rise of American Gothic" (2015) in Jerrold E. Hogle's The Cambridge Companion to Gothic Fiction (2015). The concept of the genre lies on the theories of the professors and critics Sigmund Freud's "The Uncanny" (1955) and Eve Kosofsky Sedgwick's The Coherence of Gothic Convention (1986) as well as the structuralist and post-structuralist analysis of Viktor Shklovsky's Art, as device (2015), Jan Mukařovský's "Standard language and poetic language" (1964), Mikhail Bakhtin's Estética da Criação Verbal (1997), and Julia Kristeva's Le mot, le dialogue et le roman. Shmewtikh. Recherches pour une sémanalyse (1978).

\section{The American Urban Gothic: Poe and Wharton}

As well as Horace Walpole may be considered the godfather of the British Gothic, Charles Brockden Brown ${ }^{\mathrm{ii}}$ may be considered the godfather of the genre across the Atlantic (DAVISON, 2009; 2014). Born in 1771, the son of the Quaker mercantile family from Massachusetts found himself at the core of the main of the thirteen colonies, presenting a unique view of the new republic. Having been Elijaah a supporter of the revolutionary cause, Brown witnessed the arrestment of his father and brought into inquiry the meaning and the different aspects, positive or negative, of the American dream to his novels:

"Given our greater critical awareness and appreciation of the Gothic, Brown is now popularly regarded as a pioneer whose works serve as a wellspring of themes, strategies, conventions, and types - among them Frontier Gothic, Psychological Gothic, Urban Gothic, Female Gothic (Weinstock 2011: 6), and Calvinist Gothic (Davison 2008: 166) - that continue to engage writers in America and beyond." (Davison, 2014, p. 111)

In this sense, differently from the British Gothic genre, which emerges in the eighteenth century along with the conscience of a national society being invaded and shaped by the insertion of modern concepts and ideas, illustrating the inner fears of the aristocratic world being disrupted, the American Gothic rises from the trauma of the past of the brutality of a formerly

\footnotetext{
ii The lawyer from Philadelphia is also the author of seven Gothic novels: Wieland, Ormond, Edgar Huntly, Arthur Meroyn, Stephen Calvert, Clara Howard, and Jane Talbot.
} 
colonised nation beneath the promising freedom and growth of the new American republic. According to Savoy (2014), the American Gothic relates to the traumas of the Lacanian reality. Brown, thus questions the fact that the autonomy of the individual may mean the return of the repressed irrational self, working against the benevolent, modern subject:

\begin{abstract}
"Yet it is that very struggle to give the Real a language that singularly shapes the American Gothic as broadly symptomatic of cultural restlessness, the fear of facing America's darkly pathological levels. It is also, I suggest, what gives rise to Gothic verbal figures, their urgent straining toward meaning, and their consequent strains upon the limits of language. This tension between an impossible - or at best, ineffable - reference to the Real, on the one hand, and a strange textual surface, on the other, constitute the experimental game played by American Gothic writing. Gothic images in the desire to "know" the traumatic Real of American being and yet the flight from that unbearable and remote knowledge." (p. 169)
\end{abstract}

Having witnessed the development and the growth of the main cities in this new country, the American Gothic suffers a significant shift in its structure in the sense that it changes the rural setting of the stories to the crowded and industrial scenery of the American capitals, which leads us to the new mode of the urban Gothic. The professor and critic Chad Luck (2014) points out the fact that this change in scenery contributes to the enhancement of the Gothic element since the most inner fears and desires of the American society are brought closer and more heterogenic. The narratives of the nineteenth century, then, explore the frightening feeling of the proximity of the irrational other, meaning that both reader and this alienated individual may co-exist in the same space, walk on the same streets, and may be recognised in familiar faces. This also brings us to both authors related to this article since Edgar Alan Poe is going to not only emphasise the fact that the grotesque images that take place in his stories happen in common sites, such as houses, factories, and wineries but also explore the first-person narrator so that the reader may have access to the thoughts and feelings of the American psyche, foreshadowing Freudian ideas of using the language and the structure of the narrative text to extract the uncanny element out of individuals. Edith Wharton, on the other hand, is going to make usage of the third person narrator so that the reader may have access to the dialogue, meaning that the focus lies on the appearances of reading between the lines to express the unspeakable: "So these two ladies visualized each other, each through the wrong end of her little telescope" (Wharton, 2008, p. 1374) - the reader follows the same point of view, having access through the lens the protagonists provide the audience - and to unravel the irrational other from the freedom of the New York genteel: "Wasn't it she who was the monster?" (Wharton, 2008, p. 1378).

Both works are almost a century from each other; however, in place, they find themselves quite close to one another in two aspects, since both authors are American, and the stories happen in different cities in Italy. Poe and Wharton place their stories elsewhere than the United States so that they may create a place that can mirror the image of the new country, highlighting and unravelling the deepest layers of the psyche of the American society. The first story shows the 19th-century fascination with the subject, the narrative revolves around a person being buried alive, by immurement in this case; whereas the second is set in the 1920s, but both the story's 
characters and values reflect the attitudes of upper-class society in New York in the last half of the nineteenth century.

Thus, The Cask of Amontillado tells the story of the day that Montresor took his revenge on Fortunato, a nobleman who insulted Montresor for an unspecified reason. Then, Montresor plans to murder his friend during Carnival when the man is drunk, dizzy, and wearing a particular piece of clothing that refers to a costume of a clown. He lies to Fortunato by informing him that he had pursued what might be a rare type of Amontillado. Once claiming he badly wishes his friend's specialised statement on the matter in question, Fortunato follows Montresor to the wine cellars. Montresor handles the wine, and, when they reach the opening, Montresor points Fortunato to the Amontillado, which is within. Fortunato walks in a drunken state and unsuspicious of what is about to come, and unable to resist, Montressor grabs his chance to chain his rival to the wall.

Montresor walls up the corner, burying his rival still breathing. At first, Fortunato, who gains conscience faster than Montresor had anticipated, battles and struggles with the chains in an attempt to escape. In the end, the narrator confesses that in fifty years he has not been discovered and that Fortunato's body may still be found in the same old chains behind the wall he had built himself. The murderer concludes: Requiescat In Pace!, which stands for "May he/she rest in peace!" in English. With this, Poe promotes what Jan Mukařovský (1964) called "foregrounding", because the text distorts the meaning of the Latin expression initially reasoned as a way to comfort the living and greet the dead. Peace is deformed in agony and rest in a premeditated murder.

On the other hand, Roman Fever is a short story about two old friends, Mrs. Grace Ansley and Mrs. Alida Slade, who meet at a restaurant in Rome after a long period apart. Just as in Poe's stories, the reader faces an ongoing situation right at the beginning of the narrative, thus having to catch up and fulfil the context with their possible interpretation. Both of them are accompanied by their young daughters, Barbara and Jenny, respectively, and start to remember some episodes of the past, such as the last time they had been there with their future husbands when teenagers themselves. This is the part in which the reader may find the context s/he was looking for, as the conversation goes by, according to Mrs. Slade's point of view. We can see that a youthful and romantic rivalry led Alida to nurture feelings of jealousy and hatred against Mrs. Ansley.

Through Mrs. Slade's statements, the reader may have the feeling that her character is up to something, which means the conversation is getting to a point, in which some aspect of the narrative is still missing, and something dreadful is about to come out. As so, the story reaches its climax when Mrs. Slade reveals to have written a letter to Mrs. Ansley, pretending to be her future husband, Delphin Slade, in that particular visit to Rome so many years ago, inviting her for a date at the Colosseum. The greater twist comes along with Mrs. Ansley's reply by admitting she was having an affair with Delphin, and confessing to having answered the letter, which Mrs. Slade did not know. Surprised by that allegation, Alida demands an explanation, and Grace finally says that she did not spend that night alone, because Delphin had found her letter in time, and had met her there. Mrs. Slade tries once more to rejoice at her friend by telling her that the fact that they had gathered together that night was not important since she was the one who 
became his wife and stood beside him for over twenty-five years. Mrs. Ansley, however, leaves the table stating that at least she had had Barbara.

The climax and twist once again may remind us of Poe's stories' compositions since Wharton engages the reader in the storytelling process as a beholder as s/he unravels the author's intentions. From the beginning of the story, Mrs. Slade believes that she has the upper hand, but her control slips away as the hidden narrative begins to emerge. Consequently, the abrupt ending, being a fundamental characteristic of the genre, closes the story with the revelation that Mrs, Slade was wrong to underestimate her friend's intelligence and intent. The reader is having information through Mrs. Slade's thoughts and impressions, so the effect of the impact lies here. Reaching the end of the story, we are able to state that the title is also one of the key elements Edith Wharton makes use of to get readers' attention. Roman Fever was written in the early 1930s, which tells us the city is now safe and romantic. At the time of the protagonists' mothers and grandmothers, the city was the victim of dreadful malaria, which caused great panic and paranoia to its population. Mothers, the figures who collaborate to sustain and maintain the natural order of conventions (Davison, 2009), would use the spectrum of contamination to keep their daughters' home and away from the temptations of the romantic sites of Rome. Thus, the title has a double meaning, referring once more to the inner story of the narrative, the rivalry among those old friends. Thus, Wharton also promotes "foregrounding" (Mukařovský, 1964), as the text updates, at the end, the real and hidden meaning of Roman Fever.

\section{Gothic Motifs: Foreshadowing Denouement}

The understanding that literary texts share endowments has been expanding the approach of literature as a discipline since it permeates the notion of continuity. This notion refers to the understanding of an abstract common research source, open and available to all writers, which may be consulted, not always consciously, during literary writing. This atmosphere is based on the concept of intertextuality. The term coined by Júlia Kristeva in the essay "Le mot, Le dialogue et Le Roman" (1978) means a property of the literary text, which is constructed as a "mosaic of quotations", as absorption and transformation of another text. Kristeva uttered the atmosphere of the eternal circularity between creation and quotation from the dialogical nature of the language, thus understanding the literary word as a cross of textual surfaces, as postulated by Mikhail Bakhtin (1997). According to Bakhtin (1997), a literary text is a link in the verbal communication chain. Working as the replica of the dialogue, it relates to the other works-enunciated, i. e., with those to which it responds and with those that respond to it, and at the same time, in that similar to the replica of the dialogue. Thus, each literary text is separated from others by the absolute frontier of the alternation of the speaking subjects. Therefore, the literary text is understood as a mosaic of multiple other texts written before it, and literary studies then allow us to seek to establish the links between these texts to make the work collective and emphasize the creative character of the process of text production.

Concerning group (1), Allan Poe's short story is narrated in the first person, and it is told by the murder and not by anyone else especially because there are only two main characters in all of it: the one who for any reason, such as jealousy, revenge, mental disorder, commits a crime, 
and the one who suffers the atrocities. In all of them, the titles have great importance, foreshadowing the endings: The Cask of Amontillado gives the idea of a wine cellar, which is a reference to a highly dark and isolated place where the victim is killed. Some names and objects also have an important role in the stories, helping to structure the endings by linking all parts of the texts. In The Cask of Amontillado, the victim, who is called Fortunato, is dressed as a clown, alluding to the trick he is about to be a victim of. In the middle of the story, a motto is written on the door of the graveyard: "Nemo me impune lacessit", which is Latin for "No one harms me with impunity", referring to the intention of the murderer.

In Roman Fever, when reaching the end of the story, we are able to state that the title is also one of the key elements Edith Wharton makes use of to get readers' attention. Roman Fever was an extremely aggressive and fatal type of malaria that contaminated many in the period when Mrs. Slade's and Mrs. Ansley's mothers were young adults, spreading the hysteria to the future, the second generation. However, the place was also the paradoxical attraction of young lovers since Rome itself is marked by decadence and tragedy, but also by the general idea of romance because of the weight of History spread all over it. It must also be considered the fact of the description of each of the seven hills in Rome. As the story advances, the protagonists and the reader, consequently, have access to and the view of the different historical sites, such as the Colosseum. As the conversation grows deeper, the ladies change position in the balcony of the restaurant, granting visible access to the other hills. When the narrative has finally come to an end, the narrator provides the reader with the general view of the complete landscape, meaning that once the embedded element and the foreshadowed information are revealed, the map of this Gothic setting is complete and formed.

The second information given is found in the first section of the short story. Both Mrs Slade and Mrs Ansley are seated on the balcony of a restaurant facing the Seven Hills of the Italian capital. The ladies start a conversation about how different they were from their daughters since the turn of the twentieth century had provided more freedom for the youth to come and go, and arrange marriages:

"'Oh, no,' Mrs. Ansley hastened to assure her. 'I don't care to at all. It's so lovely here; and so full of old memories, as you say.' She settled herself in her chair, and almost furtively drew forth her knitting. Mrs. Slade took sideway note of this activity, but her own beautifully cared-for hands remained motionless on her knee. 'I was just thinking,' she said slowly, 'what different things Rome stands for to each generation of travellers. To our grandmothers, Roman fever; to our mothers, sentimental dangers - how we used to be guarded! - to our daughters, no more dangers than the middle of Main Street. They don't know it - but how much they're missing!'”' (Wharton, 2008, p. 1374)

The narrator states that, while they were sitting there, they would experience " a full moon night, they would remember... Mrs. Slade's black brows drew together, as though references to the moon were out of place and even unwelcome" (Wharton, 2008, p. 1372), suggesting that what is about to come and the path that the conversation is going to take might be quite opposite to the one expected and created in the first layer of this story. The image of the full moon may also represent 
a foreshadowing element since it may refer to the idea of lunacy and the feverish sentiment of confiding lovers. The moon is usually personalised by couples and poets to express their inner feelings and desires. Moreover, the word "lunacy" has its origins in the name of the Roman goddess of the moon, Luna.

As well as Poe made usage of the sign at the entrance of the graveyard as a prophecy of what is about to happen, Wharton's narrative is not only pervaded by the atmosphere of a prophetical event, but also by the weight of the cyclical events of the first generation. In order to illustrate it, the characters comment on a common revenge young ladies would practice against their possible rivals as sending them to the coldest and most isolated historical hills of Rome so that they might become victims and surrender to the terrible disease as Mrs Slade recalls:

"'Whenever I look at the Forum from up here, I remember that story about a great-aunt of yours, wasn't she? A dreadfully wicked great-aunt?'

'Oh, yes; Great-aunt Harriet. The one who was supposed to have sent her young sister out to the Forum after sunset to gather a night-blooming flower for her album. All our great-aunts and grandmothers used to have albums of dried flowers.'

Mrs. Slade nodded. 'But she really sent her because they were in love with the same man-'

'Well, that was the family tradition. They said Aunt Harriet confessed it years afterward. At any rate, the poor little sister caught the fever and died. Mother used to frighten us with the story when we were children.'

'And you frightened me with it, that winter when you and I were here as girls. The winter I was engaged to Delphin.'

Mrs. Ansley gave a faint laugh. 'Oh, did I? Really frightened you? I don't believe you're easily frightened.'” (Wharton, 2008, p. 1375 -6)

In this sense, in Roman Fever, the space is essential for the events to take place. The city in which the story happens, Rome, Italy, is also another foreshadowing element provided by Wharton because the city is at least widely known for the birth of a powerful civilization that succeeded greatly, but that had a tragic fall. Thus, the beautiful places and monuments left behind to add to the city the feeling of adventure, especially for a romantic one due to the climate characteristics of the region that is hotter in the summer than any other country in Europe. The restaurant in which the ladies met and have the fantastic dialogue that dictates the drama they lived in has the view to those particular monuments that once again remind the characters and the reader of the feelings underneath the rocks.

Another Gothic convention that is explored by both authors is the relationship among characters and how it ended up affecting the outcome. To what Poe is concerned, the reader is presented with an encounter between two friends; however, the audience learns that one, Montressor, had been feeding a vengeful desire against the other, Fortunato, due to a previous insult. The author, thus, relies on the structure of the story within a story to pull off the veils that enable the vision and perception of the situation in question. The more the reader advances in the story, the layers are exposed, and the protagonists found themselves deeper and deeper into the wine cellar. Wharton similarly makes usage of the structure of the narrative to reveal the true 
relationship and feelings between the two ladies, demonstrating that, in fact, their own perception and recalling of the former and present events are equivocated since one feels sorrowful for the other; however, the latter had tricked the former:

"'I've come to the conclusion that I don't in the least know what they are,' said Mrs. Ansley. 'And perhaps we didn't know much more about each other.'

'No; perhaps we didn't.' Her friend gave her a shy glance. 'I never should have supposed you were sentimental, Alida.'

'Well, perhaps I wasn't.' Mrs. Slade drew her lips together in retrospect; and for a few moments the two ladies, who had been intimate since childhood, reflected how little they knew each other." (Wharton, 2008, p. 1372)

Concerning group (2), in The Cask of Amontillado, the narrator tells us that the event which is about to happen occurs during carnival season in Italy. Carnivals are known to be the mark of an inversion. In this case, it refers to the revenge of one friend on another. Along with it, Montresor makes a particular gesticulation and explains it was from the brotherhood, from the mason. Poe is playing with the meanings of the word mason, the person who is a member of this distinct group of people, and the person who builds houses, for instance. Reaching almost the end of the story, Fortunato says: "I drink to the buried that repose around us" (2004, p. 117) not knowing he is about to join them. After that, the murderer notices how drunk his victim is, and with no hesitation, locks Fortunato deep down in the graveyard.

To what Roman Fever is concerned, Wharton makes usage of the description of the protagonists both in the information provided by the narrator as the reader advances in the story and also in the poisonous commentaries that one lady makes on one another:

"Mrs. Ansley was much less articulate than her friend, and her mental portrait of Mrs. Slade was slighter, and drawn with fainter touches. "Alida Slade's awfully brilliant; but not as brilliant as she thinks," would have summed it up; though she would have added, for the enlightenment of strangers, that Mrs. Slade had been an extremely dashing girl; much more so than her daughter, who was pretty, of course, and clever in a way, but had none of her mother's - well, "vividness," some one had once called it." (Wharton, 2008, p. 1373)

By presenting such impressions, the audience becomes aware of Wharton's usage of the foreshadowing because Mrs Slade may have had an unsatisfactory life because of the nightly adventures between her friend Mrs Ansley and her husband Mr Slade in their youth. It may be noticed that the feelings between the protagonists are twisted because one character knows more details about the story than the other. Later in the story, the depiction is expanded by what Mrs. Ansley says,

"Perhaps I had. The most prudent girls aren't always prudent. What made you think of it now?' Mrs. Slade seemed to have no answer ready. But after a moment she broke out: 'Because I simply can't bear it any longer -" (Wharton, 2008, p. 1376). 
This also indicates and confirms the fact that the twisted impressions they had on one another had conducted their lives in the past twenty years. Reaching the climax of the discussion, the foreshadowed information is finally expressed in their conversation due to the fact that Mrs Slade quotes the content of the letter that Mr Slade had allegedly sent to Mrs Ansley in order for them to meet at the Colosseum with the intention of performing the vengeful act against her rival. However, what Mrs Slade was not expecting the fact that Mrs Ansley answered the letter to Mr Slade, who the reader learns in the following sentences of the narratives agreed to meet with her. In an attempt to recover herself, Mrs Slade expresses the fact that she was the one to marry Mr Slade and spend twenty years of their lives beside him. Mrs Ansley decides to leave the premises and replies that at least she had Barbara. The short story finally unravels the last of the veils.

Another element that must be considered is the hours and the moments of the day that the events and the facts of the conversation take place. Because, as Sedgwick (1986) explains it, there are periods in which the daylight might mingle between dark and brightness not making it discernible whether it is the sunrise or the sunset. Thus, it increases the supernatural and fantastic elements of the narrative since the lack of rationality makes room for those elements to happen and indicate to the audience that something out of the ordinary is about to be depicted.

\section{Final Considerations}

Having emerged in the eighteenth century and presented its peak in the nineteenth century, the Gothic literature acquired its space and popularity by describing and depicting the most inner fears and impulses of the society of its time, which was facing the drastic changes of the Modern Age, such as the concept of individual liberty and equality. Walpole's masterpiece makes it possible for other stories and tales to take place, and, along with the expansion and the development of the Enlightenment world, the Gothic genre crossed the ocean to find a feverish soil to express the contradictory feelings and the conflict of the morality of a new nation, such as the new-born country, the United States. Along with the promise of becoming the land of the American dream, in which the new republic aimed at the developments of the new century, Gothic literature explored the traumas of a society that had witnessed the horrifying effects of the colonisation process. With the improvement of the main cities, Edgar Alan Poe questioned the fact that the feeling of freedom might relinquish the irrational other embedded in the individuals by illustrating the thoughts and the psyche of the American society of the nineteenth century, demonstrating that the alienated mind might be among the familiar faces and not in the distant rural world, for instance. Edith Wharton, as a consequence of the Gothic offspring, explores the traumas of the American genteel of the twentieth century, demonstrating with a telescope the contradictions of the modern individual in an attempt to cover the irrational desires of the other-self within. By making usage of the structuralist approach provided by the professor and critic Eve Kosofsky Sedgwick (1986), both authors enjoy the frame of a story within another story to depict the unspeakable traumas of American society.

Edith Wharton's Roman Fever is the type of story which caught the attention mostly because of the way it is structured and the themes with which the author is dealing in it. By 
giving and dosing information throughout the story, Wharton was successful in having her public captured in wanting to know more and trying to understand what was happening underneath the primary story.

Calculating every step and feeling of the characters and the narrative through sharp dialogues, reminding us of the way Edgar Allan Poe used to do it, the author also managed to deal with the dispute among friends. However, most importantly, it was a tool to exemplify the kind of society America was facing at that time, the early nineteenth century. The facade of politeness is deconstructed as the reminiscing focuses on the particular incident. This is an accurate depiction of the way society women spoke to one another, and also allows Wharton to seductively suspend the truth in front of the reader until the story's final explosive exchanges.

Gathering all the clues together, as shown in the tables below, it is possible to come to some interesting conclusions:

Table 1: Group 1

\begin{tabular}{|c|c|c|}
\hline \multicolumn{3}{|c|}{ GROUP 1} \\
\hline Stories & \multirow{2}{*}{$\begin{array}{l}\text { The Cask of } \\
\text { Amontillado }\end{array}$} & \multirow[t]{2}{*}{ Roman Fever } \\
\hline Elements & & \\
\hline The title & A & 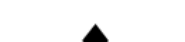 \\
\hline Objects & & \\
\hline Expression & $\hat{~}$ & \\
\hline Location & & \\
\hline
\end{tabular}

Source: elaborated by the authors.

Table 2: Group 2

\begin{tabular}{|l||c|c||}
\hline \multicolumn{2}{|c|}{ GROUP 2 } \\
\hline \hline Stories & The Cask of Amontillado & Roman Fever \\
\hline Elements & & \\
\hline \hline Descriptions & $\diamond$ & \\
\hline \hline Confessions & $\diamond$ & \\
\hline \hline \begin{tabular}{l|l|} 
Unreliable \\
Narrators
\end{tabular} & $\diamond$ & \\
\hline \hline & & \\
\hline
\end{tabular}

Source: elaborated by the authors. 
There are elements from both groups in all stories and not so many of a group and a few from the other, forming a perfect balance among the elements that create the original great impact on the reader when s/he gets to the end. By doing that, it is possible to establish that Poe deals with the narrative as if he were dealing with a mathematical equation. Therefore, we may state that Edith Wharton follows the same pattern as Poe, and think about her stories the same way as well. However, as we have already affirmed, the themes dealt in the stories are quite different, since Wharton is working with the multiple masks and hidden lives of the society she is in when Edgar Allan Poe is dealing with the gothic literary characteristics that would be the main aim of authors at his time.

Gothic stories would usually explore the inner fears of the society of the time. Since this period lasted for over two centuries, the gothic element would be adapted as society grew mentally. It is so embedded in the literary tradition that we may notice that, although the stories analysed are a century apart from each other, the latest presents the most important gothic characteristic, which is the structure of a primary story, leading to a secondary story, leading to the next inner plot and so on. Whereas Gothic novels make usage of Gothic motifs as elements to unravel the veils of the structuralist pattern of the genre so that the reader may have access to the core of the problem in question and, afterward, expect for the balance that the endings provide to soothe the audience, American Gothic short stories make usage of the motifs to foreshadow the climax of the story at the moment which the secondary story, meaning the embedded narrative, comes to the surface, causing the revelation of the uncanny and abruptly finishing the plot.

\section{Acknowledgements}

We would like to acknowledge the support of the Brazilian National Council for Scientific and Technological Development (CNPq).

\section{Conflict of Interest Statement}

The authors declare no conflicts of interests.

\section{About the Authors}

Caroline Navarrina de Moura is a PhD student and MA in Literature Studies (English Literature) at the Post-Graduate Program in Letras in the Federal University of Rio Grande do Sul (UFRGS). Her research focuses on Gothic Literature.

Lis Yana de Lima Martinez is a PhD student and MA in Literature Studies (Literary Theory, Literary Critique and Comparative Literature) at the Post-Graduate Program in Letras in the Federal University of Rio Grande do Sul (UFRGS). Her research focuses on Media studies and on English Literature. Currently she is a CNPQ Scholarship researcher. 


\section{References}

Bakhtin, Mikhail, 1997. Estética da Criação Verbal. São Paulo: Martins Fontes.

Bense, Max, 2009. Pequena Estética. Translated by J. Guinsburg. São Paulo: Pespectiva.

Brown, Charles Brockden, 2008. Arthur Mervyn; or, Memoirs of the Year 1793: With Related

Texts. London: Hackett Publishing Company, Inc.

Brown, Charles Brockden, 1988. Edgar Huntly, Or, Memoirs of a Sleep-Walker. London: Penguin Classics.

Brown, Charles Brockden, 1978. Memoirs of Stephen Calvert. Frankfurt: Peter Lang International Academic Publishers.

Brown, Charles Brockden, 2009. Ormond; or, the Secret Witness: With Related Texts. London: Hackett Publishing Company, Inc.

Brown, Charles Brockden, 2016. The Novels of Charles Brockden Brown: Jane Talbot, Vol. V. Australia: Leopold Classic Library.

Brown, Charles Brockden, 2011. The Novels of Charles Brockden Brown: Ormond, Or The Secret Witness. Clara Howard, Or, The Enthusiasm of Love. Charleston: Nabu Press.

Brown, Charles Brockden, 1991. Wieland and Memoirs of Carwin the Biloquist London: Penguin Classics.

Davison, Carol Margaret, 2009. History of the Gothic: Gothic Literature 1764 - 1824. Valeta: Gutenberg Press.

Davison, Carol Margaret, 2014. Charles Brockden Brown: Godfather of the American Gothic. In: Crow, Charles L. A Companion to American Gothic. West Sussex: Wiley Blackwell.

Freud, Sigmund, 1955. 'The uncanny'. In: FREUD, Anna. An Infantile Neurosis and other Works. London: The Hogarth Press.

Kristeva, Julia, 1978. Le mot, le dialogue et le roman. Shmewtikh. Recherches pour une sémanalyse. Paris: Seuil.

Lewis, Matthew G., 2016. The Monk. Oxford: Oxford University Press.

Luck, Chad, 2014. George Lippard and the Rise of the Urban Gothic. In: CROW, Charles L. A Companion to American Gothic. West Sussex: Wiley Blackwell.

Mukařovský, Jan, 1964. Standard language and poetic language. In: GARVIN, Paul L. (ed.). A Prague School reader on aesthetics, literary structure, and style. Washington,-DC: Georgetown University Press.

Poe, Edgar Allan, 1846. The Philosophy of Composition. [Text 2], Grahams Magazine, vol. XVIII, $\mathrm{n}^{\mathrm{o}} 4$.

Radcliffe, Ann, 2008 The Italian. Oxford: Oxford University Press.

Radcliffe, Ann, 2001. The Mysteries of Udolpho. London: Penguin.

Reeve, Clara, 2008. The Old English Baron. Oxford: Oxford University Press; Reissue edition.

Savoy, Eric, 2014. The rise of American Gothic". In: HOGLE, Jerrold E. The Cambridge companion to gothic fiction. Cambridge: Cambridge University Press.

Segdwick, Eve Kosofsky, 1986. The Coherence of Gothic Conventions. Routledge Kegan \& Paul. 

to their work. Under the terms of this license, no permission is required from the author(s) or publisher for members of the community to copy, distribute, transmit or adapt the article content, providing a proper, prominent and unambiguous attribution to the authors in a manner that makes clear that the materials are being reused under permission of a Creative Commons License. Views, opinions and conclusions expressed in this research article are views, opinions and conclusions of the author(s). and European Journal of Literature, Language and Linguistics Studies shall not be responsible or answerable for any loss, damage or liability caused in relation to/arising out of conflicts of interest, copyright violations and inappropriate or inaccurate use of any kind content related or integrated into the research work. All the published works are meeting the Open Access Publishing requirements and can be freely accessed, shared, modified, distributed and used in educational, commercial and non-commercial purposes under a Creative Commons Attribution 4.0 International License (CC BY 4.0). 